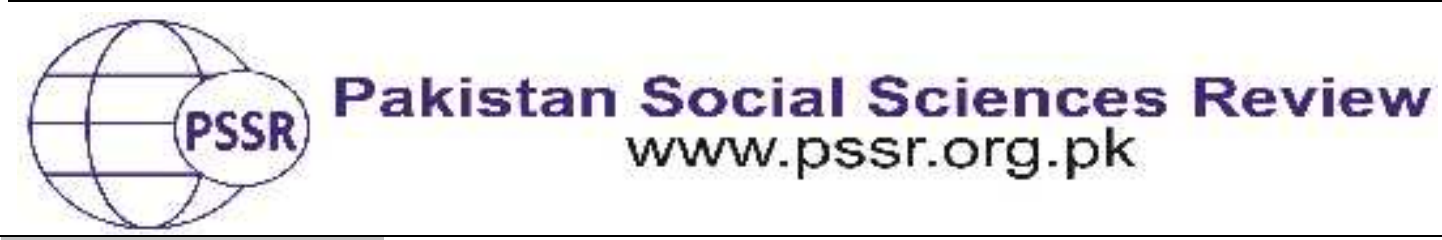

RESEARCH PAPER

\title{
Impact of Politics and Policy on University Students' Attitudes towards the Use of English in Pakistani Universities
}

\author{
Dr. Humaira Irfan
}

Assistant Professor, Department of English, University of Education, Lahore, Punjab, Pakistan

\begin{tabular}{|c|c|}
\hline PAPER INFO & ABSTRACT \\
\hline $\begin{array}{l}\text { Received: } \\
\text { February 11, } 2020 \\
\text { Accepted: } \\
\text { March 15, } 2020 \\
\text { Online: } \\
\text { March 30, } 2020\end{array}$ & $\begin{array}{l}\text { The study has explored the language politics and policy in } \\
\text { relation to university students' negative and positive attitudes } \\
\text { towards the use of English in Pakistani universities. The } \\
\text { researcher has collected the qualitative and quantitative data } \\
\text { from two large scale public universities located in Lahore, }\end{array}$ \\
\hline $\begin{array}{l}\text { Keywords: } \\
\text { Higher Education, } \\
\text { Language } \\
\text { Attitudes, } \\
\text { Language Policy, } \\
\text { Language } \\
\text { Problems }\end{array}$ & $\begin{array}{l}\text { Pakistan. } 451 \text { university students and } 35 \text { faculty members } \\
\text { participated in the research. The evidence demonstrates that } \\
\text { worth mentioning outcome of Pakistan's language policy is } \\
\text { university students' inadequate proficiency in English. It is } \\
\text { evidently found out that university students' language problems }\end{array}$ \\
\hline $\begin{array}{l}\text { Corresponding } \\
\text { Author }\end{array}$ & $\begin{array}{l}\text { result into negative attitudes to use English confidently in } \\
\text { universities. However, the university students are eager to } \\
\text { improve their English language skills. English is a prerequisite }\end{array}$ \\
\hline 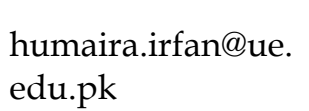 & $\begin{array}{l}\text { for higher education and instrumental for technological and } \\
\text { socio-economic development of the country. }\end{array}$ \\
\hline
\end{tabular}

\section{Introduction}

The paper discusses language in education policy and practice, language attitudes, English language policies of Pakistan, research methods, analysis and interpretation of data, and the discussion of results.

Pakistan is a plural society as it is marked with multilingualism, multiculturalism and multiethnicity. Each province in Pakistan i.e. Punjab, Sindh, Balouchistan, Khyber Pakhtoonkhwa has distinct languages and cultural diversity (Akhtar, 1989; Irfan, 2018). For instance, Punjab has Punjabi and Seraiki, Sindh has Sindhi, Urdu and Gujarati, Kyber Pakhtoonkhwa's languages are Pashto and Hindko and Balochistan has multiple languages such as, Balochi, Brahui, Pashto, Seraiki and Punjabi (Haque, 1983; Rahman, 2006). Coleman Report (2010, p.16) describes that in Pakistan English and Urdu are deployed as official languages, 85\% 
of the population speak seven macro languages (Punjabi, Seraiki, Sindhi, Pashto, Balochi, Brahui and Hindko) and 15\% population speak 55 other regional languages.

The purpose of the study is to explore the impact of English language policies on postgraduate students' attitudes towards English in universities. Pakistan is a plural society; hence its language in education policy is riddled with politics. The major outcome of ineffective implementation of language in education policy is that students lack proficiency in English. The choice of a language(s) as a medium of instruction is difficult to decide, thus, the low quality in education is one of the main concerns and students continue to face numerous problems and difficulties to cope with higher education. At the same time, it is positively acknowledged that English is needed for higher education and socio-economic development of the country. Therefore, universities should take appropriate remedial measures to develop students' proficiency in English.

\section{Literature Review}

Before initiating the debate on English language policies of Pakistan to explore how they are responsible for postgraduate students' lack of proficiency in English, a few ideas about language policy and practice can be discussed. Prunty (1985, p. 136) views the policy as authoritative distribution of values and principles which involves the concept of power and governmental control. Kaplan (1990) believes that language-in-education policy is secondary to a country's national education policy. Those languages in a country thrive and develop that perform significant social, cultural, political and economic functions. The regional languages surrender to powerful global languages under the impact of modernization, economic mobility and societal forces (Egginton \& Wren, 1997; Kaplan \& Bauldauf, 1997). In Pakistan, Urdu and English are dominant languages whereas regional languages except Sindhi never managed to gain importance in education.

This study is concerned with university students' negative and positive attitudes for English language. Baker (1988, p.112) discusses that attitudes are crucial for decay or growth and destruction or survival of any language. The attitudes are affected by experiences and globalization to determine the status of a language in society. The language attitudes are complex as both negative and positive attitudes are associated with a language. Further, language learning is dependent on motivation (Curtin, 1979). The motivated and demotivated students have diverse perceptions of their teachers, curriculum and peers. These perceptions develop their negative and constructive attitudes towards using a language in universities (Irfan, 2018; Mansoor, 2005).

In the $16^{\text {th }}$ century, English was introduced by the British in Indo-Pak subcontinent that was officially recognized with Macaulay's minutes of 1835 (Mahboob \&Talaat, 2008). The British government embarked on the journey of expansion of English language and English medium universities. It is important to note that learning of English was for the elites and vernacular medium education 
was reserved for the poor people. This education system created classification in the society and widened the gap between "have and have not" (Rahman, 1996, p. 34). English in British India flourished because of economic and social mobility associated with the language and the people learned English either by contact or formal education (Mahboob \& Talaat, 2008).

After independence, English was maintained as an official language as it had deeply penetrated into social, economic, educational and political structures of the region (Baumgardner, 1993; Mahboob, 2002, 2003). Like most ex-colonial countries, implementation of effective language policy was confronted with complexity because of various languages striving to be accepted as the national language. Though, Urdu acquired the status of the national language, it was ensured that it should not be the only language of the state machinery (Mahboob, 2002, p. 21). Haque (1983) also asserts, 'the use of English was inevitable for system maintenance: the ruling elite were trained to do their official work in English. English perforce continued to be the official language of Pakistan'. The report of University Grant Commission (1982, p. 14) states: 'English would continue to be used in the foreseeable future as the language of technology and of international communication'.

In language policies, 1947 to 1958 period significantly implies the rift between Bengali and Urdu. These two languages were dominant languages at the time of independence. Urdu is an emblem of Muslim Unity (Rahman, 1996) whereas Bengali was the native language of East Pakistan (modern Bangladesh). Urdu was declared as the national language in 1947, Mahboob (2002, p. 21) views that suppression of Bangla was symbolically meant to restrain and repress the Bengali culture. This injustice created negative sentiments among the people of East Pakistan. Consequently, ethno-linguistic movements eventually separated East Pakistan from West Pakistan and Bangladesh as an independent state emerged on the surface of the globe in 1971. This struggle between Urdu-Bengali languages critically reflects the complex linguistic situation in Pakistan right after independence. However, scarcity of corpus planning in Urdu restricted it to be the only official language. The position of English was maintained to be the official language to run the functions and affairs of the state smoothly.

Sharif commission in 1959 explored the critical language issues. It made Urdu (national language) the medium of instruction in West Pakistan and Bangla was implemented as the medium of instruction in East Pakistan for public schools (class 6 to Matric). Commission stated, 'English should continue as second language since advance knowledge which was in English was needed for advanced study and research' (Sharif Commission, 1959, p.281). The complex linguistic situation resulted in annulment of Bangladesh from Pakistan. Shortly afterwards, in 1971-1972, riots in Sindh sparked off as Sindhi desired their native language Sindhi to be medium of instruction in schools. The upshot of these riots was that Sindhi was declared the medium of instruction in Sindh the primary level (Rahman, 1996). 
General Zia-ul-Haq's language policy in 1978 purposefully brought about the drastic changes targeted towards English so that Urdunization and Islamisation policies can be implemented. The public schools imposed Urdu as the medium of instruction from levels 1-6. However, elite schools were not affected. This policy presumed that medium of instruction would also be Urdu in colleges and universities. General Zia ul Haq's dual policy was immensely criticized as hypocritical (Mansoor, 2005). It is believed that lack of well-researched and balanced language planning and policy development was mainly a reason behind the ethnic and linguistic divide among Pakistani people (Mahboob, 2002; 2009). The governments in power from 1988 did not frame any real language policies because languages were a politically charged and controversial issue (Mahboob, 2002).

In a nutshell, it can be argued that in all education policies, English language learning problems of the students and pedagogical challenges of English teachers have never been seriously addressed. In addition, no government or regime has stressed the burning issue of helping the students to overcome their language learning difficulties at university level. The solution that has been offered in policies is that after some years Urdu could be the medium of instruction in universities. Hence, a realistic language policy should be framed for higher education that reflects the language attitudes and language learning, and targets needs of students (Mansoor, 2005).

\section{Material and Methods}

The researcher deployed questionnaires and focus group interviews as methods to probe into the research issues. She used likert scale for questionnaires and constructed semi-structured questions for focus group interviews. The informants were M.A Education students and faculty members of two reputed public universities located in Lahore, Pakistan. She invited them for voluntary participation in her research. The participants belonged to different economic and social classes. In addition, ethnic and linguistic variety was also diverse. The informants were from different educational backgrounds and medium of instruction in schools and colleges was different.

Overall, 451 M.A Education students and 35 faculty members participated in the survey method. Afterwards, they were invited to make contribution to focus group interviews. Six participants for each focus interview were randomly selected from those who volunteered to fill in the questionnaires. Therefore, the researcher audio recorded two focus group interviews of university teachers and 2 focus group interviews of M.A Education students. The researcher assured informants of complete anonymity and confidentiality regarding their identity and information collected from them.

The researcher used SPSS Version 19 to explore and analyze the data. She applied descriptive statistics to get frequencies and percentages. Then, she merged both universities' frequency tables to show comparative results. In the tables given 
below, 'SU' stands for Sunflower University and 'RU' means Rose University. The focus group interviews were also transcribed and organised in accordance with themes. Therefore, findings of the quantitative and the qualitative data collected from the universities were used to interpret and understand the attitudes of M.A Education students concerning English as a medium of instruction, and any problems that they experience.

\section{Analysis and Interpretation of Results}

The research surveyed postgraduate students and university teachers' attitudes towards the use of English in universities. The following tables represent comparative results of the survey. Table 1 shows that $47 \%$ teachers of one university strongly agree and $47 \%$ agree, and $55.6 \%$ teachers of other university agree that English is integrated with educational, socio-politico and economic life.

\section{Results and Discussion}

\section{Table 1}

Integration of English with educational, socio-politico and economic life

\begin{tabular}{ccccc}
\hline $\begin{array}{c}\text { English integrated with } \\
\text { educational, socio-politico and } \\
\text { economic life }\end{array}$ & $\begin{array}{c}\text { Frequency } \\
\text { (SU) }\end{array}$ & $\begin{array}{c}\text { Percent } \\
\text { (SU) }\end{array}$ & $\begin{array}{c}\text { Frequency } \\
\text { (RU) }\end{array}$ & $\begin{array}{c}\text { Percent } \\
\text { (RU) }\end{array}$ \\
\hline Neither agree nor disagree & 1 & 5.9 & 3 & 16.7 \\
\hline Agree & 8 & 47.1 & 2 & 11.1 \\
\hline Strongly agree & 8 & 47.1 & 10 & 55.6 \\
\hline Total & 17 & 100.0 & 3 & 16.7 \\
\hline & & & 18 & 100.0 \\
\hline
\end{tabular}

Figure 1 represents M.A Education students' language problems (see Figure 1).

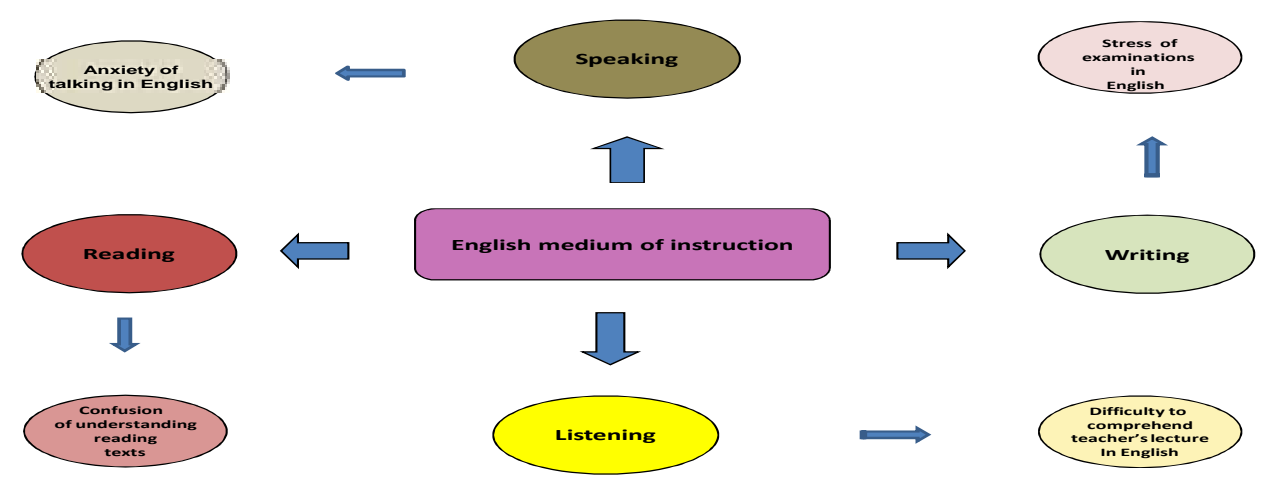

Figure 1: Language problems emerging from EMI 
Table 2 illustrates that first university's 45\% students agree and 35\% strongly agree, and second university's $49 \%$ students believe that English as a medium of instruction creates language problems.

Table 2

Language problems as an outcome of EMI

\begin{tabular}{ccccc}
\hline $\begin{array}{c}\text { Language problems as a } \\
\text { EMI }\end{array}$ & $\begin{array}{c}\text { Frequency } \\
\text { (SU) }\end{array}$ & $\begin{array}{c}\text { Percent } \\
\text { (SU) }\end{array}$ & $\begin{array}{c}\text { Frequency } \\
\text { (RU) }\end{array}$ & $\begin{array}{c}\text { Percent } \\
\text { (RU) }\end{array}$ \\
\hline Strongly disagree & 6 & 2.7 & 18 & 8.0 \\
\hline Disagree & 33 & 14.6 & 21 & 9.3 \\
\hline Neither agree nor disagree & 5 & 2.2 & 23 & 10.2 \\
\hline Agree & 102 & 45.1 & 111 & 49.3 \\
\hline Strongly agree & 80 & 35.4 & 52 & 23.1 \\
\hline Total & 226 & 100.0 & 225 & 100.0 \\
\hline
\end{tabular}

Table 3 depicts that $62 \%$ students of one university and $66 \%$ students of other university believe that English is required for higher education.

Table 3

English essential for Higher Education (HE)

\begin{tabular}{ccccc}
\hline English essential for HE & $\begin{array}{c}\text { Frequency } \\
\text { (SU) }\end{array}$ & $\begin{array}{c}\text { Percent } \\
\text { (SU) }\end{array}$ & $\begin{array}{c}\text { Frequency } \\
\text { (RU) }\end{array}$ & $\begin{array}{c}\text { Percent } \\
\text { (RU) }\end{array}$ \\
\hline Strongly disagree & 2 & .9 & 8 & 3.6 \\
\hline Disagree & 5 & 2.2 & 1 & .4 \\
\hline Neither agree nor disagree & 4 & 1.8 & 14 & 6.2 \\
\hline Agree & 74 & 32.7 & 53 & 23.6 \\
\hline Strongly agree & 141 & 62.4 & 149 & 66.2 \\
\hline Total & 226 & 100.0 & 225 & 100.0 \\
\hline
\end{tabular}

Table 4 indicates that $64 \%$ teachers of one university strongly agree and $50 \%$ teachers of other university agree that English is essential for future development of the country.

Table 4

English essential for future development

\begin{tabular}{ccccc}
\hline $\begin{array}{c}\text { English essential for } \\
\text { future development }\end{array}$ & $\begin{array}{c}\text { Frequency } \\
\text { (SU) }\end{array}$ & $\begin{array}{c}\text { Percent } \\
\text { (SU) }\end{array}$ & $\begin{array}{c}\text { Frequency } \\
\text { (RU) }\end{array}$ & $\begin{array}{c}\text { Percent } \\
\text { (RU) }\end{array}$ \\
\hline Strongly disagree & 1 & 5.9 & 3 & 16.7 \\
\hline Neither agree nor disagree & 2 & 11.8 & 1 & 5.6 \\
\hline Agree & 3 & 17.6 & 9 & 50.0 \\
\hline Strongly agree & 11 & 64.7 & 5 & 27.8 \\
\hline Total & 17 & 100.0 & 18 & 100.0 \\
\hline
\end{tabular}

The students develop negative attitudes towards English as a medium of instruction. The result shows that one university's 37.6\% students agree and $29.6 \%$ strongly agree whereas other university's $40.4 \%$ agree and $14.2 \%$ strongly agree that 
they experience tension about taking notes in English due to weak listening comprehension (see Table 5).

Table 5

Tension about taking notes

\begin{tabular}{ccccc}
\hline Tension about taking notes & $\begin{array}{c}\text { Frequency } \\
\text { (SU) }\end{array}$ & $\begin{array}{c}\text { Percent } \\
\text { (SU) }\end{array}$ & $\begin{array}{c}\text { Frequency } \\
\text { (RU) }\end{array}$ & $\begin{array}{c}\text { Percent } \\
\text { (RU) }\end{array}$ \\
\hline Strongly disagree & 19 & 8.4 & 31 & 13.8 \\
\hline Disagree & 45 & 19.9 & 44 & 19.6 \\
\hline Neither agree nor disagree & 10 & 4.4 & 27 & 12.0 \\
\hline Agree & 85 & 37.6 & 91 & 40.4 \\
\hline Strongly agree & 67 & 29.6 & 32 & 14.2 \\
\hline Total & 226 & 100.0 & 225 & 100.0 \\
\hline
\end{tabular}

It is seen that one university's $37.6 \%$ informants agree and $32.3 \%$ strongly agree, and other university's participants' response rate shows that $40.8 \%$ agree and $17.8 \%$ strongly agree about anxiety when teachers talk with them in English (see Table 6).

Table 6

Anxiety when a teacher talks in English

\begin{tabular}{ccccc}
\hline $\begin{array}{c}\text { Anxiety when a teacher } \\
\text { talks in English }\end{array}$ & $\begin{array}{c}\text { Frequency } \\
\text { (SU) }\end{array}$ & $\begin{array}{c}\text { Percent } \\
\text { (SU) }\end{array}$ & $\begin{array}{c}\text { Frequency } \\
\text { (RU) }\end{array}$ & $\begin{array}{c}\text { Percent } \\
\text { (RU) }\end{array}$ \\
\hline Strongly disagree & 16 & 7.1 & 25 & 11.1 \\
\hline Disagree & 45 & 19.9 & 29 & 12.9 \\
\hline Neither agree nor disagree & 7 & 3.1 & 40 & 17.8 \\
\hline Agree & 85 & 37.6 & 91 & 40.4 \\
\hline Strongly agree & 73 & 32.3 & 40 & 17.8 \\
\hline Total & 226 & 100.0 & 225 & 100.0 \\
\hline
\end{tabular}

It is noted that $35 \%$ students agree and $30.1 \%$ strongly agree while other university's $38.7 \%$ agree and $14.7 \%$ strongly agree that they have confusion about understanding reading texts (see Table 7).

Table 7

Confusion about reading texts

\begin{tabular}{ccccc}
\hline $\begin{array}{c}\text { Confusion about reading } \\
\text { texts }\end{array}$ & $\begin{array}{c}\text { Frequency } \\
\text { (SU) }\end{array}$ & $\begin{array}{c}\text { Percent } \\
\text { (RU) }\end{array}$ & $\begin{array}{c}\text { Frequency } \\
\text { (SU) }\end{array}$ & $\begin{array}{c}\text { Percent } \\
\text { (RU) }\end{array}$ \\
\hline Strongly disagree & 21 & 9.3 & 29 & 12.9 \\
\hline Disagree & 49 & 21.7 & 42 & 18.7 \\
\hline Neither agree nor disagree & 9 & 4.0 & 34 & 15.1 \\
\hline Agree & 79 & 35.0 & 87 & 38.7 \\
\hline Strongly agree & 68 & 30.1 & 33 & 14.7 \\
\hline Total & 226 & 100.0 & 225 & 100.0 \\
\hline
\end{tabular}


Table 8 reveals that $36.7 \%$ respondents agree and $30.1 \%$ strongly agree whereas $39.1 \%$ of other university agree and $19.1 \%$ strongly agree that examinations in English cause stress.

Table 8

Stress of Examinations

\begin{tabular}{ccccc}
\hline Stress of examinations & $\begin{array}{c}\text { Frequency } \\
\text { (SU) }\end{array}$ & $\begin{array}{c}\text { Percent } \\
\text { (SU) }\end{array}$ & $\begin{array}{c}\text { Frequency } \\
\text { (RU) }\end{array}$ & $\begin{array}{c}\text { Percent } \\
\text { (RU) }\end{array}$ \\
\hline Strongly disagree & 21 & 9.3 & 30 & 13.3 \\
\hline Disagree & 43 & 19.0 & 40 & 17.8 \\
\hline $\begin{array}{c}\text { Neither agree nor } \\
\text { disagree }\end{array}$ & 11 & 4.9 & 23 & 10.2 \\
\hline Agree & 83 & 36.7 & 89 & 39.6 \\
\hline Strongly agree & 68 & 30.1 & 43 & 19.1 \\
\hline Total & 226 & 100.0 & 225 & 100.0 \\
\hline
\end{tabular}

Table 9

Anxiety about writing skill

\begin{tabular}{ccccc}
\hline Writing Skill & $\begin{array}{c}\text { Frequency } \\
\text { (SU) }\end{array}$ & $\begin{array}{c}\text { Percent } \\
\text { (RU) }\end{array}$ & $\begin{array}{c}\text { Frequency } \\
\text { (SU) }\end{array}$ & $\begin{array}{c}\text { Percent } \\
\text { (RU) }\end{array}$ \\
\hline Strongly disagree & 5 & 2.2 & 20 & 8.9 \\
\hline Disagree & 25 & 11.1 & 26 & 11.6 \\
\hline $\begin{array}{c}\text { Neither agree nor } \\
\text { disagree }\end{array}$ & 12 & 5.3 & 29 & 12.9 \\
\hline Agree & 104 & 46.0 & 78 & 34.7 \\
\hline Strongly agree & 80 & 35.4 & 72 & 32.0 \\
\hline Total & 226 & 100.0 & 225 & 100.0 \\
\hline
\end{tabular}

Finally, $46 \%$ informants agree, $35.4 \%$ strongly agree and other university's results show that $34.7 \%$ students agree and $32 \%$ strongly agree that writing is a difficult skill for them (see Table 9).

Interestingly, findings from focus group interviews strengthen results obtained from the survey method. English is a medium of instruction in higher education, therefore, students are required to read advanced literature for Masters in Education but as many students come from different educational backgrounds, they confront language problems. A university teacher comments, 'the students are uncomfortable with English medium of instruction---they struggle to comprehend the language for grasping the information about the courses'. Another teacher remarks, 'we have been bilingual and mostly use Urdu language because students lack proficiency in English' It is important to take into account postgraduate students' language problems sparked off by English as a medium of instruction. These language problems eventually lead to negative attitudes towards using English in universities. They feel more comfortable if they are allowed to use Urdu language in classroom. For example, a student says, 'we understand concepts if our teachers teach in Urdu'. 
Similarly, another student asserts, 'I believe EMI is a real problem for students because of inadequacy in vocabulary, pronunciation, and tenses of English language'.

The informants express their views about politics in English language policies and what renders their ineffective implementation in the country. A teacher reports, 'Pakistan's language policies are riddled with politics that revolves around Urdu or English medium of instruction controversy'. Another faculty member views the situation as, 'Politicians intentionally have created the conflict between Urdu and English'. A student's comment is worth mentioning, 'religious education, cultural heritage, egoistic attitudes of diverse ethnic groups such as, Balouchis, Punjabis, Seraiki, Sindhi, Pathans obstruct development and execution of beneficial language policy'.

However, informants express highly positive attitudes with regards to socioeconomic development of Pakistan. A teacher believes, 'we use English for investment, good political relations and technological growth'. Another thoughtfully reports, 'English is a prerequisite for socio-economic development, therefore, Pakistanis should receive effective coaching in it from school to university level.'

\section{Results and Discussion}

Significantly, it is noted that language policies in Pakistan are complicated and problematic since independence. It is perceived that many ethno-linguistic movements across the country released violence and bloodshed. The Urdu-Bengali controversy consequently led to separation of East Pakistan from West Pakistan in 1971 (Rahman, 1996). All language policies from 1948 till 1988 have conspicuously stated that EMI at higher education will be replaced with Urdu (national language) after 10 or 15 years. Urdunization and Islamization of General Zia ul Haq's policy extremely intensified Urdu and English controversy. The governments from 1988 onwards to present day also failed to frame the beneficial language policies because languages are a politically charged issue in Pakistan. There is a reciprocal corelationship between political changes and changes in language policies. The country has political instability that most probably never endorsed implementation of appropriate practical and realistic steps in this direction.

The study under investigation has measured the postgraduate students' attitudes towards using English in universities. It is useful to appraise people's attitudes towards languages because the status of any language in a society is dependent on public's negative and positive attitudes. The language attitudes play a crucial role for a language death or survival of a language in society. The ethnic identity also influences the language attitudes.

The research investigates, though English is considered indispensable for entry into high governmental, military, judiciary, and civil bureaucracy, the language policy and planning commissions never raised the issue of improving university students' proficiency in English. It's a total lack of involvement on the government's side to deal with this vital issue. Further, it is stated in all national 
education policies that English will be the medium of instruction in higher education but no education policy and planning commission has carefully measured the reasons for postgraduate students' lack of proficiency in English. The findings reveal that the postgraduate students experience language problems on account of imposition of English medium of instruction in universities. Most of the postgraduate students agree that they have language problems resulting from English as a medium of instruction (see Table 3). They have problems in all four skills which consequently lead to negative attitudes (see Figure 2). They are unable to comprehend teacher's lecture (see Table 5); hesitate to speak English in classroom (see Table 6); find reading texts hard to understand (see Table 7) and feel that writing is a complex skill (see Table 9). They also undergo stress of taking examinations in English because they lack accuracy and fluency in English (see Table 8). Thus, they feel anxiety in responding to teacher; have confusion about interpreting reading texts and experience tension about writing assignments and examinations.

The teachers in focus group interviews discuss that they are instructed to teach in English but they have to be bilingual to explain the concepts because their postgraduate students struggle to grasp the concepts entirely if they are taught using EMI. They are anxious learners because of their language learning difficulties. Their mandatory four skills listening, speaking, reading and writing are not up to the required standard. The postgraduate students confess that EMI is a problem for them and are contented if their teachers use Urdu language to clarify the concepts.

The underlying concern of research is that although English is taught as a compulsory subject at all levels of education; the postgraduate students in universities are not proficient in English. They are neither fluent in written nor in spoken English. Therefore, people are not comfortable with it because they are diffident to communicate in it effectively.

The findings of the research also reveal postgraduate students' positive attitudes towards English because it is politically, economically and culturally a dominant language and the other languages are without power and prestige. In Pakistan, English is used for education, administration, mass media and information technology. Thus, English is essential for future development of Pakistan (see Table 4). The results show that informants believe that the role of English is important for Pakistan because economic and technological advancements could not be possible without English. English is an international language and Pakistanis need English to communicate with people of other countries. Moreover, print and electronic media are in English. The proficiency in English is considered crucial for a number of reasons including higher studies, getting jobs, and entering into the corridors of power through joining the armed forces, judiciary, bureaucracy, and multinational companies. Thus, it is considered an important tool for social and economic mobility. 


\section{Conclusions and Implications}

In short, a rational and pragmatic language policy in higher education is needed that comprises language attitudes and language learning needs of students. The results indicate that M.A Education students have developed negative attitudes towards using English in universities. At the same time, students express their keen desire to learn English in order to have an access to higher education and to obtain well-paid jobs. English is imperative for the socio-economic development of the country. Thus, it must be assured by Higher Education Commission (HEC) and Ministry of Education that if English is indispensable for the socio-economic, technological, political development, then people should receive training in English from school to university level. Therefore, universities might take remedial measures to promote English, this will, in the long run be of benefit to students. 


\section{References}

Akhtar, R. (1989). Pakistan Year Book: 1988-1989. Karachi: East and West Publishing Company.

Baker, C. (1988). Key issues in bilingualism and bilingual education. Clevedon: Multilingual Matters.

Baumgardner, R.J. (1993). English Language in Pakistan. Karachi: Oxford University Press.

Coleman, H. (2010). Teaching and Learning in Pakistan: The Role of Language in Education. Islamabad: The British Council.

Curtin, J.B. (1979). Attitudes to Language Learning. ELT Language Journal, 33 (4), 281-284.

Eggington, W., \& Wren, H. (1997). Language Policy: Dominant English, Pluralistic Challenges. Australia: John Benjamins.

Haque, A.R. (1983). The Position and Status of English in Pakistan. World Englishes, 2 (1): 6-9.

Irfan, H. (2018). The Policy and Practice of English Medium of Instruction (EMI). Newcastle: Cambridge Scholars Publications

Kaplan, R.B. (1990). Literacy and Language Policy. Lenguas Modernas, 17.

Kaplan, R.B. \& Bauldauf Jr., R.B. (1997). Language Planning: From Practice to Theory. Clevedon: Multilingual Matters.

Mahboob, A. (2002) No English, no future: language policy in Pakistan. In Samuel Obeng \& Beverly Hartford (eds.), Political Independence with Linguistic Servitude: The Politics about Languages in the Developing World. New York: NOVA Science.

Mahboob, A. (2003) The English Language in Pakistan: a brief overview of its history and linguistics. Pakistan Journal of Language, 4: 1-28.

Mahboob, A., \& Talaat, M. (2008) English language teachers and teacher education in Pakistan. In S. Dogancay-Aktuna \& J. Hardman (Eds.), Global English Language Teacher Education (pp. 3-26). Washington, D.C: TESOL Publications. Mahboob, A. (2009) English as an Islamic language: a case study of Pakistani English, World Englishes, 28(2): 175-189.

Mansoor, S. (2005) Language Planning in Higher Education: A Case Study of Pakistan. Karachi, Oxford University Press. 
National Education Policy (1959) Islamabad: Ministry of Education Press.

National Education Policy (1973) Islamabad: Ministry of Education Press.

Prunty, J. (1985) Signposts for a Critical Policy Analysis. Australian Journal of Education, 29 (2): 133-140.

Rahman, T. (1996) Language and Politics in Pakistan. Karachi, Oxford University Press.

Rahman, T. (2006) Language Policy, Multilingualism, and Language Vitality in Pakistan. Trends in Linguistics, 73-106.

University Grants Commission (1982) Report study Group on the teaching of languages. Islamabad, Government of Pakistan. 